\title{
Identification of a Smad4/YY1-Recognized and BMP2-Responsive Transcriptional Regulatory Module in the Promoter of Mouse GABA Transporter Subtype I (Gat1) Gene
}

\author{
Minghui Yao (姚明慧), ${ }^{1,5}$ Gang Niu (牛钢 $),{ }^{4}$ Zhejin Sheng (盛哲津), ${ }^{2}$ Zhugang Wang (王铸钢 ), ${ }^{3}$ and Jian Fei (费俭 ${ }^{2,3}$ \\ ${ }^{1}$ Laboratory of Molecular Cell Biology, Institute of Biochemistry and Cell Biology, Shanghai Institutes for Biological Sciences, Chinese Academy of Sciences, \\ Shanghai 200032, China, ${ }^{2}$ School of Life Science and Technology, Tongji University, Shanghai 200092, China, ${ }^{3}$ Shanghai Research Center for Model \\ Organisms, Pu Dong, Shanghai 201203, China, ${ }^{4}$ Department of Biochemistry, University of Hong Kong, Hong Kong 852, China, and ${ }^{5} \mathrm{Graduate}$ School of \\ Chinese Academy of Sciences, Beijing 100049, China
}

GABAergic dysfunction is implicated in a variety of neurodevelopmental and psychiatric disorders. The mechanisms underlying GABAergic differentiation, however, are not well understood. GABA transporter 1 (Gat1; Slc6a1) is an essential component of the GABAergic system, and its ectopic mRNA expression may be responsible for GABAergic malfunction under different pathological conditions. Thus, monitoring the transcriptional regulation of gat 1 may help to elucidate the mechanisms that govern the differentiation of GABAergic neurons. In this study, we identified a promoter region that is sufficient to recapitulate endogenous gat 1 expression in transgenic mice. A 46 bp cis-regulator in the promoter sequence was responsible for the stimulation of bone morphogenetic protein-2 (BMP2) on gat1 expression in cortical cortex. Furthermore, our study demonstrated that Smad4 and YY1 are physically bound to the element and mediate both the negative and positive regulatory effects in which BMP2 can affect the balance. In summary, we have identified a Smad4/YY1-based bidirectional regulation model for GABAergic gene transcription and demonstrated a molecular cue important for the differentiation of GABAergic neurons.

\section{Introduction}

Aberrant development and dysfunction of GABAergic neurons are implicated in a variety of neurodevelopmental and psychiatric disorders, such as epilepsy (DeFelipe, 1999; Cossart et al., 2005), schizophrenia (Woo et al., 1998; Lewis et al., 1999, 2005; Volk and Lewis, 2002; Ruzicka et al., 2007), and anxiety disorders (Baraban, 2002; Heilig and Thorsell, 2002). Signaling molecules that regulate the acquisition and maintenance of GABAergic phenotype include bone morphogenetic proteins (BMPs) (Li et al., 1998; Mabie et al., 1999; Gulacsi and Lillien, 2003), Notch (de la Pompa et al., 1997; Kabos et al., 2002), and glial cell-derived neurotrophic factor (Pozas and Ibáñez, 2005), as well as basic helix-loop-helix (Casarosa et al., 1999; Bae et al., 2000; Fode et al., 2000; Miyoshi et al., 2004; Schuurmans et al., 2004; Nakatani et al., 2007) and homeodomain (Anderson et al., 1997; Sussel et al.,

Received June 22, 2009; revised Jan. 20, 2010; accepted Feb. 1, 2010.

This work was supported by grants from the National Natural Science Foundation of China (30670438), the National Key Basic Research Program (2002CB713803), the National High Technology Research and Development Program (2008AA02Z126), the Science and Technology Commission of Shanghai Municipality (07DZ19503, 06DZ19004), and E-Institutes of Shanghai Municipal Education Commission (E03003). We are grateful to Dr. Fang Huang, Dr. Mei Yu, and Jiajuan Shen for technical assistance, and Dr. Kehong Zhang from Ivy Editing for language editing. We thank Xixia Zhou for animal care.

Correspondence should be addressed to Dr. Jian Fei, School of Life Science and Technology, Tongji University, 1239 Siping Road, Shanghai 200092, China. E-mail: jfei@mail.tongji.edu.cn.

DOI:10.1523/JNEUROSCI.2964-09.2010

Copyright $\odot 2010$ the authors $\quad 0270-6474 / 10 / 304062-10 \$ 15.00 / 0$
1999; Kroll and O’Leary, 2005) transcription factors. However, the molecular mechanisms regulating gene transcription resulting in GABAergic differentiation are still far from clear.

The GABAergic phenotype requires coordinated activation of glutamate decarboxylases (Gad1-2), the plasma membrane GABA transporters (Gat1-4), and the vesicular inhibitory amino acid transporter ( $V g a t)$. In Caenorhabditis elegans, transcription factor $u n c-30$ has been found to determine GABAergic phenotype by regulating the transcriptions of unc-25/gad and unc-47/vgat in a coordinated manner (Eastman et al., 1999; Westmoreland et al., 2001). It enlightens us to elucidate the mechanisms underlying the differentiation of GABAergic neurons by monitoring the transcriptional regulation of functional genes in GABAergic neurons.

GABA transporter 1 (Gat1; Slc6a1) is the major neural GABA transporter, and plays an important role in the termination of GABAergic transmission and the regulation of extracellular GABA concentration (Chiu et al., 2002). Studies of mice overexpressing, or deficient in, gat1 suggest that gat1 is associated with seizures (Ma et al., 2001; Zhao et al., 2003; Chiu et al., 2005) and emotional behaviors such as anxiety (Chiu et al., 2005; Liu et al., 2006). Alterations of gat 1 expression on transcription level play a key role in some GABAergic-related pathological circumstances such as epilepsy (Fueta et al., 2003; Sperk et al., 2003; Jiang et al., 2004), schizophrenia (Woo et al., 1998; Lewis et al., 1999; Volk et al., 2001; Volk and Lewis, 2002), and substance abuse (Peng and 
Simantov, 2003; Zink et al., 2004). Furthermore, polymorphism in the $5^{\prime}$-flanking region of gat 1 is highly associated with anxiety disorders (Thoeringer et al., 2009). A recent study demonstrated that $21 \mathrm{bp}$ insertion polymorphism increases gat promoter activity (Hirunsatit et al., 2009).

In this study, mouse gat1 gene promoter was identified in transgenic mice and a 46 bp cis-regulatory element was found to regulate gat 1 transcription activity in the cerebral cortex. In addition, we found evidence suggesting that functional interaction between Smad4/YY1 and the 46 bp element mediates both the negative and positive regulatory effects in which morphogenetic protein 2 (BMP2) can affect the balance. To the best of our knowledge, this is the first report of bidirectional in vivo transcriptional regulation of gat 1 .

\section{Materials and Methods}

Rapid amplification of $5^{\prime} c D N A$ ends. Total RNA was isolated from mouse brain and subjected to $5^{\prime}$-race analysis (Invitrogen). The primer used for the first step of amplification was 5'-GCCTTCTTCTGCACCTTGACTACC-3', located within exon 3. 5'-Race was performed by incubating with an aliquot of first-strand cDNA, a nested PCR primer positioned within exon 3 (5'-CAGGTGGGCGCGAGATGTC-3'), and an abridged anchor primer. The PCR conditions were: initial denaturation at $94^{\circ} \mathrm{C}$ for $5 \mathrm{~min}, 35 \mathrm{cycles}$ of $30 \mathrm{~s}$ at $94^{\circ} \mathrm{C}, 1 \mathrm{~min}$ at $58^{\circ} \mathrm{C}$, and $1 \mathrm{~min}$ at $72^{\circ} \mathrm{C}$. The resulting products were cloned into pMD-18T vector (TaKaRa) and sequenced to determine the transcription initiation site(s).

Constructs and mutagenesis. A $5.7 \mathrm{~kb}$ fragment of mouse gat 1 promoter was generated by PCR with mouse genomic DNA as a template. The forward primer was from base 66540243 to 66540265 of the $5^{\prime}$-flanking region of gat1 gene (GI:149255466) with an additional MluI site (italics) (5'-TTAACGCGTGAGAGAGCACAACGCAGGAACAG-3'). The reverse primer was from base 66545546 to 66545570 of the downstream of the exon 1 with an additional XhoI site (underlined) (5'TTACTCGAGCGAACGAACTAGGACATAGACGGC-3'). The $5.7 \mathrm{~kb}$ MluI-XhoI fragment was cloned into $\mathrm{pGL}_{3}$-basic (Promega). This construct is referred to as $-5377 /$ luc throughout this manuscript. The construct $-3006 /$ luc was assembled by deleting the KpnI-BamHI fragment from the $-5377 /$ luc construct. Constructs containing fragments of gat 1 gene promoter beginning at $-2135,-2085,-1978,-1782,-1493$, $-1090,-891,-706,-333,-288,-241,-167,-93$, or +109 from the transcription initiation site were prepared in a similar manner using forward primers with a MluI site at $5^{\prime}$ terminal (italics) $5^{\prime}$-TTAACGCGTTGCTTTGGTCACGGTGTCTCTTC-3' (-2135/luc), 5' TTAACGCGTGAGGTCAAACAGATGCAAAG-3' (-2085/luc), 5' TTAACGCGTCCTGGATTTGGTTCCCAGCAC-3' (-1978/luc), 5' TTAACGCGTCTTCAGGCACAGCTGGATCAC-3' (-1782/luc), 5'TTAACGCGTATGAGACGTGGGGAGAAGACC-3' (-1493/luc), 5' TTAACGCGTGTCTGGGCTCTCGAAAGGTTG-3' (-1090/luc), 5' TTAACGCGTAGCCTAGATGCTTGTGGGAGG-3' (-891/luc), 5' TTAACGCGTTGGGGAACATGGAAAAGGGAGAG-3' (-706/luc), 5' TTAACGCGTGTGACAGAGCCAGAGAAACCAAG-3' (-333/luc), 5' TTAACGCGTGAGGCCAGGAGACTGAAGGAG-3' (-288/luc), 5' TTAACGCGTGGGAGCAGGGCTGGGAGAGAG-3' (-241/luc), 5' TTAACGCGTGGCAAGGCGGGCAGGGCCTAG-3' (-167/luc), 5' TTAACGCGTGAGGAGGCAGGCAGAGGGAGG-3' (-93/luc), 5' TTAACGCGTCTAGAGAGCTGAGAGGTTGCAGG-3' (+109/luc), respectively. The reverse primer was identical to that used to generate the construct $-5377 /$ luc. Restriction analysis and sequencing were used to verify the location of the promoter.

Deletion was introduced to construct $-5377 \mathrm{~m} / \mathrm{luc}$ using a two-step PCR method with the $-5377 /$ luc DNA as the template. Two overlapping oligonucleotides were synthesized: $-5377 \mathrm{~m} / \mathrm{luc}$ (forward) 5 '-CTCCTGGCCTCATCTCTCTTGGAAGCATTGTGG- $3^{\prime}$ and $-5377 \mathrm{~m} / \mathrm{luc}$ (reverse) 5'-GAGAGATGAGGCCAGGAGACTGAAGGAG-3'. The first-step PCR was initiated using one of these primers and an appropriate primer which was used to generate the construct $-5377 /$ luc. The products of the
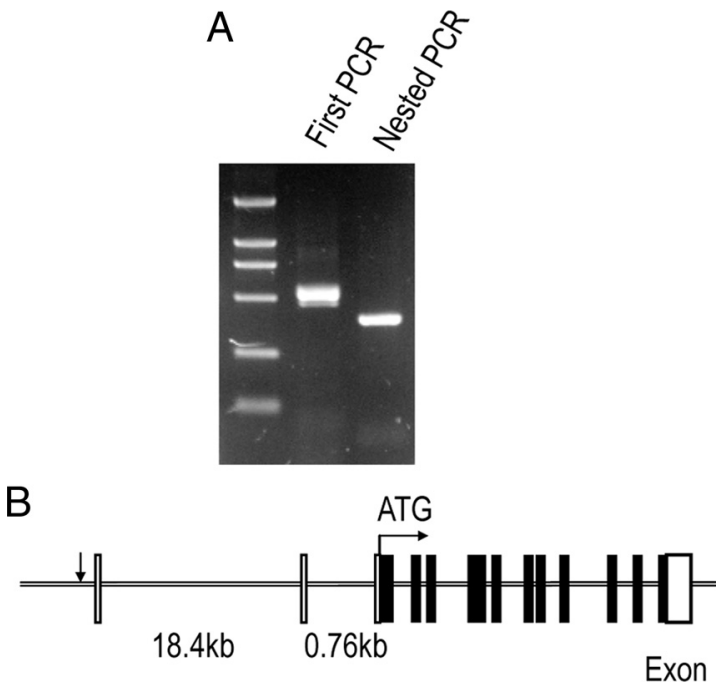

Figure 1. $\quad 5^{\prime}$-Race determination of transcription initiation site(s) in mouse gat 1 gene. $\boldsymbol{A}, \mathrm{Gel}$ analysis of the first $P C R$ and nested $P C R$ products from $5^{\prime}$-race with RNA derived from mouse brain. $\boldsymbol{B}$, Schematic representation of mouse gat1 genomic structure. The transcription initiation site is indicated by arrow. Open boxes represent the noncoding region and black boxes represent the coding region. The start of translation occurs in exon 3, as indicated by ATG.

Table 1. Transgene expression in gat1(5.7)lacz transgenic mice

\begin{tabular}{llc}
\hline & \multicolumn{2}{l}{ gat1(5.7)lacz transgenic founder } \\
\cline { 2 - 3 } Transgenic mice tissue & $88 \mathrm{~F}(n \geq 3)$ & $32 \mathrm{~F}(n \geq 3)$ \\
\hline Brain & 100 & 100 \\
Heart & 0 & 11.4 \\
Lung & 2.9 & 5.4 \\
Liver & 5.6 & 4.4 \\
Spleen & 4.4 & 3.0 \\
Kidney & 0.3 & 5.1 \\
\hline
\end{tabular}

LacZ mRNA expression in the brain of each line was artificially set at 100. Three replicates of each reaction were performed.

first-step PCR were used as a template for the second-step PCR with a set of primers used to generate the construct $-5377 / \mathrm{luc}$. The resulting product was digested with MluI and XhoI and cloned into the vector $\mathrm{pGL}_{3}$ basic. The resulting construct lacked fragment -333 to -288 , and was verified with sequencing.

The sequence of the mouse gat1 gene was analyzed for potential transcription factor binding sites with P-Match program (BioBase, Wolfenbüttel, Germany) using Transfac 6.0 Public database.

Short hairpin RNA (shRNA) oligonucleotides were designed to specifically target either smad4 or $y y 1$. Two different shRNA oligonucleotides of smad4: shRNA1 5'-CCAGCTACTTACCATCATA-3' (Thuault et al., 2006) and shRNA2 5'-GCCATAGTGAAGGACTGTT-3' (Rees et al., 2006). Two different shRNA oligonucleotides of $y y 1$ : shRNA1 $5^{\prime}$ GAACTCACCTCCTGATTAT-3' (Allouche et al., 2008) and shRNA2 $5^{\prime}$-TGACAGGCAAGAAACTCCC-3'. Two nonspecific control shRNA oligonucleotides with a similar GC content as smad4 shRNA and $y y 1$ shRNA were used. The inhibitory efficiency of each shRNA was determined by Western blot assay.

Generation of transgenic mice. The pSV $\beta$-galactosidase was obtained from Promega. The $1690 \mathrm{bp}$ HindIII-XbaI fragment was isolated from $\mathrm{pGL}_{3}$-basic. The $3744 \mathrm{bp}$ HindIII-XbaI fragment from pSV $\beta$-galactosidase was inserted to $\mathrm{pGL}_{3}$-basic at the HindIII site. The resulting fusion gene consisted of the Escherichia coli gpt gene fragment containing its translation initiation site, the $L a c Z$ gene encoding $\beta$-galactosidase from amino acid position 9 and the simian virus 40 (SV40) fragment with the polyadenylation signal. The $5.7 \mathrm{~kb}$ fragment, containing the $5^{\prime}$-flanking sequences, exon 1 and part of intron 1, was introduced to the plasmid carrying the LacZ gene at the XhoI and SmaI sites. The final fusion gene was referred to as gat1(5.7)lacz. gat1 (5.7m) lacz was prepared in a 

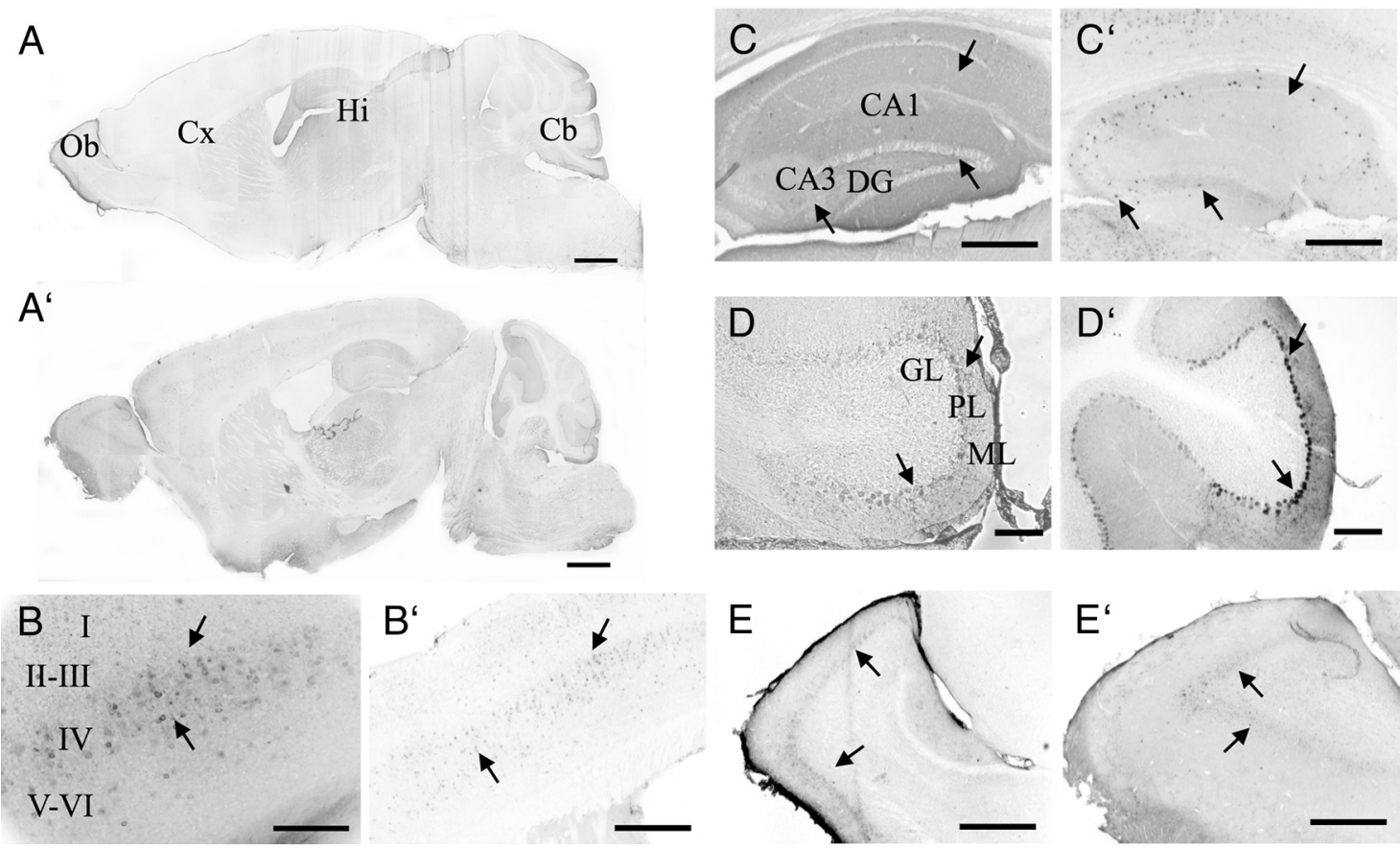

Figure 2. Histological detection of GAT1 and LacZ in the brain of adult gat1(5.7)lacz mice. $A-E^{\prime}$, Sagittal brain sections from gat 1(5.7)lacz transgenic mice were stained by anti-GAT1 antibodies $(\boldsymbol{A}-\boldsymbol{E})$ or anti-LacZ antibodies $\left(\boldsymbol{A}^{\prime}-\boldsymbol{E}^{\prime}\right)$. Shown are images of whole brain $\left(\boldsymbol{A}, \boldsymbol{A}^{\prime}\right)$, cerebral cortex $\left(\boldsymbol{C} ; \boldsymbol{B}, \boldsymbol{B}^{\prime}\right)$, hippocampus $\left(\mathrm{Hi} ; \boldsymbol{C}, \boldsymbol{C}^{\prime}\right)$, cerebellum $\left(\boldsymbol{C b} ; \boldsymbol{D}, \boldsymbol{D}^{\prime}\right)$, and olfactory bulb $\left(0 \mathrm{~b} ; \boldsymbol{E}, \boldsymbol{E}^{\prime}\right)$. Abbreviations for this and subsequent figures: CA1, CA3, Fields of the hippocampus; $D G$, dentate gyrus; GL, ML, and PL are granule, molecular, and Purkinje cell layers, respectively. In all panels, arrows denote immunopositive cells. Scale bars: $\boldsymbol{A}_{,} \boldsymbol{A}^{\prime}, 1 \mathrm{~mm} ; \mathbf{D}, \boldsymbol{D}^{\prime}, 100 \mu \mathrm{m} ; \boldsymbol{B}, \boldsymbol{B}^{\prime}, \boldsymbol{C}, \boldsymbol{C}^{\prime}, \boldsymbol{E}, \boldsymbol{E}^{\prime}, 400 \mu \mathrm{m}$.

similar manner to construct $-5377 \mathrm{~m} / \mathrm{luc}$. All clones were verified by sequencing.

gat1(5.7) lacz and gat1(5.7m)lacz constructs were linearized with ScaI and subsequently purified with the Qiaex II Gel Extraction kit (Qiagen). The constructs were microinjected into fertilized eggs of C57BL/6J $\times$ DBA/2J hybrid mice. Founders were identified by PCR analysis of tail genomic DNA with primers that amplify a $470 \mathrm{bp}$ region spanning the junction between the mouse gat 1 promoter and the lacZ cDNA. Primers for PCR were (forward) 5'-AGCCCCGGCCGCAGGTAGGAA-3' and (reverse) 5'-GCTGGCGAAAGGGGGATGTGCT-3'.

Quantitative real-time PCR. Total RNA was extracted from mouse tissues (brain, heart, lung, liver, spleen, and kidney) using Trizol (Invitrogen). RNA samples were treated with RNase-free DNase I (TaKaRa) for $30 \mathrm{~min}$ at $37^{\circ} \mathrm{C}$ to eliminate DNA contamination. Reverse transcription was performed with M-MLV (Promega). Fluorescent signals were generated using SYBR Green PCR Master Mix (Applied Biosystems). PCRs for each gene of interest were run in triplicate on Rotor-Gene 3000 as follows: $10 \mathrm{~min}$ at $95^{\circ} \mathrm{C}$ and 40 cycles of $15 \mathrm{~s}$ at $94^{\circ} \mathrm{C}, 15 \mathrm{~s}$ at $66^{\circ} \mathrm{C}$, and $30 \mathrm{~s}$ at $72^{\circ} \mathrm{C}$. Primer sequences were: for lac $Z$ (the target gene), (forward): 5'-TCAATCCGCCGTTTGTTCCCAC-3', and (reverse): 5'-TCCAGATAACTGCCGTACTCCAGC-3'; and for gapdh (the internal control), (forward): 5'-TGATGACATCAAGAAGGTGGTGAAG-3', and (reverse): $5^{\prime}$-TCCTTGGAGGCCATGTGGGCCAT-3'. A melting curve analysis was performed at the end of the PCR cycle. Electrophoresis with $2 \%$ agarose gel was used to verify the amplification a single product. Experimental controls included non-reverse-transcribed RNA samples. Data were analyzed by Rotor-Gene software to determine the threshold cycle (CT) above the background for each reaction. Normalization was performed using the $2^{-\Delta \Delta \mathrm{CT}}$ method (Livak and Schmittgen, 2001). The $\triangle \mathrm{CT}$ variability calculation revealed a slope value close to zero in a cDNA dilution over a 100-fold range in three independent experiments.

Tissue processing and immunocytochemistry. Heterozygous transgenic mice (2 months old) were deeply anesthetized and perfused with $4 \%$ paraformaldehyde in $0.1 \mathrm{M}$ PB. Whole brains were removed, postfixed in the same fixative for $4 \mathrm{~h}$, and cryoprotected in $20 \%$ glycerol/PB overnight at $4^{\circ} \mathrm{C}$. Sagittal sections $(30 \mu \mathrm{m})$ were cut and then stored in an ethylene glycol based cryoprotective solution at $-20^{\circ} \mathrm{C}$.
Immunohistochemical staining of free-floating sections was performed using an immunoperoxidase kit (VECTA ABC Kit, Vector Laboratories). The sections were incubated in $0.3 \% \mathrm{H}_{2} \mathrm{O}_{2}$ in PBS for $30 \mathrm{~min}$ at room temperature to quench endogenous peroxidase. Sections were then incubated in $10 \%$ normal goat serum for $1 \mathrm{~h}$ at room temperature to block nonspecific binding. Sections were incubated with rabbit antiGAT1 (1:100 dilution; Millipore Bioscience Research Reagents) or rabbit anti-LacZ (1: 2000 dilution; Abcam) in 1\% normal goat serum overnight at $4^{\circ} \mathrm{C}$. After rinsing, the sections were incubated for 30 min each with an appropriate biotinylated goat secondary antibody (ProteinTech Group) and an avidin-biotin complex solution. Staining was developed for 10 min in nickel-DAB solution $(0.3 \%)$. No staining was observed in the control experiments, in which primary antibodies were omitted. Nontransgenic controls failed to be stained by anti-LacZ antibody under these conditions.

For immunofluorescence staining, free-floating sections were washed twice in PBS and then blocked with $10 \%$ normal goat serum in PBS. Doublelabeling studies were performed using non-cross-reacting secondary antibodies after primary antibody incubation. The sections were examined under a Nikon Eclipse TE 2000-U fluorescence microscope with filters suitable for selectively detecting the fluorescence of FITC (green) and Cy3 (red) or under a light microscope. For colocalization, images from the same section but showing different antigen signals were overlaid.

The number of positively labeled cells and the intensity of the immunopositive signal were estimated by a blinded observer using Image-Pro Plus program (Media Cybernetics). For an unbiased determination, every 20th serial section at $\sim 1.2-4.2 \mathrm{~mm}$ from the midline were selected. For each brain, five sagittal sections were analyzed, and the average was used to calculate the group means ( $n=5$ brains).

Cell culture, transfections, and reporter gene assays. NIH 3T3 fibroblasts and Neuro 2a (mouse neuroblastoma) cell lines were grown in DMEM (Invitrogen) with $10 \%$ newborn calf serum supplemented with 100 units $/ \mathrm{ml}$ penicillin and $100 \mathrm{mg} / \mathrm{ml}$ streptomycin (Invitrogen). The mouse embryo teratocarcinoma P19 cells were cultured in DMEM/F12 (Invitrogen) containing 10\% fetal bovine serum.

Primary cortical neuron cultures were obtained from embryonic day 18 (E18) mouse embryos, dissociated with $0.125 \%$ trypsin (Invitrogen) for $15 \mathrm{~min}$ at $37^{\circ} \mathrm{C}$, and then dissociated mechanically with a glass Pas- 

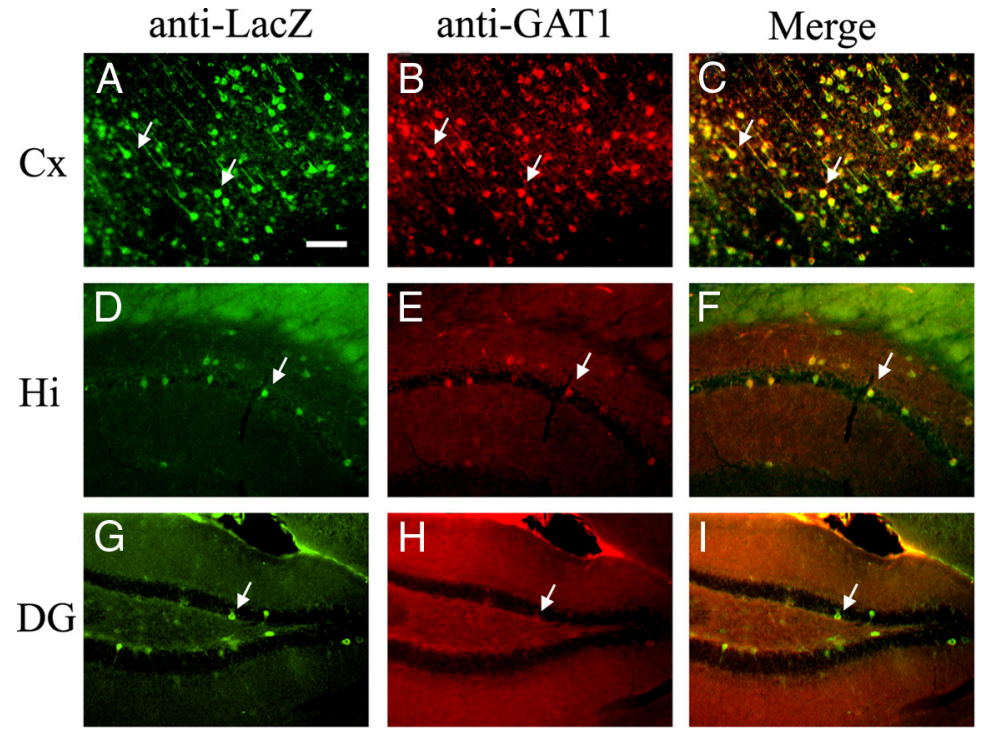

$\mathrm{Cb}$
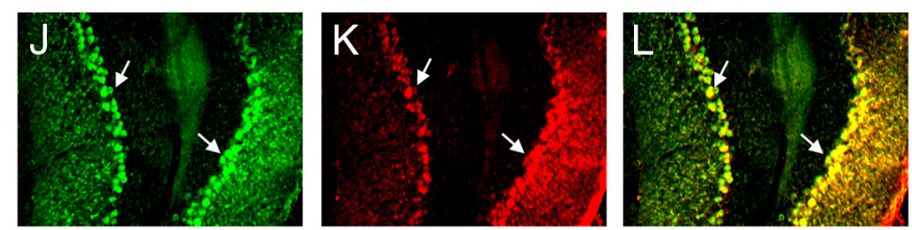

$\mathrm{Ob}$
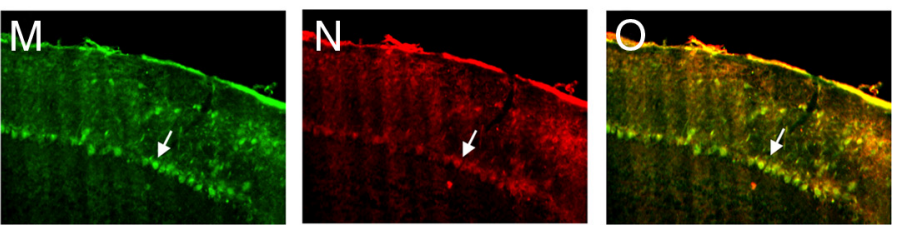

Figure 3. Colocalization of LaCZ and GAT1 in the brain of adult gat7(5.7)lacz mice. $\boldsymbol{A}-\mathbf{0}$, Sagittal brain sections from gat1(5.7)lacz transgenic mice were stained by anti-LacZ antibodies (green) and anti-GAT1 antibodies (red). Shown are images of cerebral cortex ( $(X$; $\boldsymbol{A}-\boldsymbol{C}$, hippocampus (Hi; $\boldsymbol{D}-\boldsymbol{F})$, dentate gyrus ( $(\mathrm{G} ; \mathbf{G}-\boldsymbol{I})$, cerebellum $(\mathrm{Cb} ; \boldsymbol{J}-\mathbf{L})$, and olfactory bulb $(0 \mathrm{~b} ; \boldsymbol{M}-\mathbf{0})$. The third window in each row represents the merging of the red and green channels. Yellow staining indicates colocalization of LaCZ and GAT1. A-0, Arrows denote immunopositive cells. See legend of Figure 2 for abbreviations not used in the text. Scale bar, $100 \mu \mathrm{m}$.

teur pipette. Cells were plated in Neurobasal medium (Invitrogen) containing $0.5 \mathrm{~mm}$ L-glutamin (Invitrogen), and 2\% B-27 supplement (Invitrogen) on poly-L-lysine-coated plates. On day 4 in vitro, onequarter of the media was replaced with fresh media containing cytosine arabinoside (final concentration, $2 \mu \mathrm{M}$ ) to eliminate non-neuronal cells.

Primary neural stem cell (NSC) cultures were obtained from E14 mouse embryos. Dissected whole brain was transferred to ice-cold Hank's balanced salt solution (Invitrogen) and mechanically dissociated into a single-cell suspension with a fire-polished Pasteur pipette. Cells were seeded in noncoated T-25 culture flask in DMEM/F12 (Invitrogen) containing 2\% B-27, $20 \mathrm{ng} / \mathrm{ml}$ epidermal growth factor (Peprotech) and $20 \mathrm{ng} / \mathrm{ml}$ basic fibroblast growth factor (Peprotech) at a density of $100,000 \mathrm{cell} / \mathrm{s} / \mathrm{ml}$. Primary neurospheres were dissociated by incubation with Accutase (Millipore Bioscience Research Reagents) and reseeded in fresh media at 50,000 cells/ml until secondary spheres were generated. All spheres used for experiments were passaged at least once. All cell lines were kept at $37^{\circ} \mathrm{C}$ in a humidified atmosphere containing $5 \% \mathrm{CO}_{2}$.

Cells were transfected in Opti-MEM (Invitrogen) with Lipofectamine2000 (Invitrogen). The pRL-SV40 or pRL-TK vector (Promega) was used as internal control. P19 cells and NSCs were treated with bone BMP2 (Peprotech) at 20 and $10 \mathrm{ng} / \mathrm{ml}$, respectively (Lee et al., 2000). Cells were harvested $48-72 \mathrm{~h}$ post-transfection and assayed for reporter gene activity with a Dual-Luciferase Reporter Assay System (Promega).

Nuclear extract preparation and electrophoretic mobility shift assay. Nuclear extracts were prepared according to the method of Jiang et al. (2008). Biotin-labeled double-stranded oligonucleotide from mouse gat1 gene promoter region (probe A 5'-GTGACAGAGCCAGAGAAAC-
CAAGAGACCAATTAAGGTAGACCTTT-3') or reported smad4-binding site (probe SBE 5'-AGACAGACAATGTCTAGTCTATTTGAAATGCCTGA-3') was used as a probe. LightShift chemiluminescent EMSA kit (PIERCE) was used for the binding reactions. Before the addition of biotin-labeled probe, $2 \mu \mathrm{g}$ of nuclear extracts was incubated for $10 \mathrm{~min}$ at room temperature in $10 \mu \mathrm{l}$ of reaction buffer. Biotinlabeled probe was then added, and the incubation was allowed to proceed for $20 \mathrm{~min}$ at room temperature. Protein-DNA complexes were separated on nondenaturing polyacrylamide gels. In competition experiments, the nuclear extracts were preincubated with excess unlabeled double-stranded oligonucleotides for 10 min. The sequences of the competitor $\mathrm{A}_{\mathrm{SBE} 3 \mathrm{~m}}$ and SBEm oligonucleotides were: $\mathrm{A}_{\mathrm{SBE} 3 \mathrm{~m}}$ 5'-GTGACAGAGCCAGAGAAACCAATTTTTCAATTAAGGTAGACCTTT-3', SBEm 5' -AGACAGACAATGTTTATTCTATTTGAAATGCCTGA-3', and their complementary strands.

Chromatin immunoprecipitation assay. Chromatin immunoprecipitation (ChIP) assays were performed by using a ChIP assay kit (Millipore Biotechnology). Briefly, P19 cells or primary cultured neurons were cross-linked for $10 \mathrm{~min}$ at $37^{\circ} \mathrm{C}$ by the addition of formaldehyde (final concentration, $1 \%$ ). After washing with cold PBS, cells were resuspended in SDS lysis buffer supplemented with protease inhibitors and incubated on ice for $10 \mathrm{~min}$. Cell lysate was subsequently sonicated seven times with $3 \mathrm{~s}$ bursts at $40 \mathrm{~W}$ in a Sonifier (JY92-2D, Ningbo Scientz Biotechnology) to yield input DNA enriched with fragments between 200 and $1000 \mathrm{bp}$ in size. A small proportion of the lysate was immediately heated at $65^{\circ} \mathrm{C}$ for $4 \mathrm{~h}$ in the presence of $5 \mathrm{M} \mathrm{NaCl}$ to reverse the crosslinks, and was later used for monitoring equal DNA amounts for ChIP (Input). Sonicated lysate obtained from $\sim 1 \times 10^{6}$ cells was reconstituted in $2 \mathrm{ml}$ of ChIP dilution buffer with protease inhibitors. To reduce nonspecific background, the lysate was treated with salmon sperm DNA/protein A-agarose beads for $30 \mathrm{~min}$ at $4^{\circ} \mathrm{C}$. The precleared lysate was immunoprecipitated with $5 \mu \mathrm{g}$ of rabbit anti-YY1 (Santa Cruz Biotechnology), anti-Smad4 (Santa Cruz Biotechnology), or the same amount of normal rabbit IgG at $4^{\circ} \mathrm{C}$ overnight. Immune complexes were collected with salmon sperm DNA/protein A-agarose. After elution of immune complexes, cross-linking was reversed as described above, and the DNA was then purified by a typical phenol/chloroform procedure and ethanol precipitation. Real-time PCR analysis of ChIP DNA was conducted in three independent experiments, quantified using the standard curve method on ABI 7300 thermocycler, and normalized to Smad4 bound to the region from -333 to -288 of mouse gatl gene (set at $100 \%$ ). The primers used were: (forward) 5'-ACACATCCTCCAAGACCAATCCT-3' and (reverse) 5' -GGCCTCCACCCTCCTTCA-3'.

Statistics. Results are expressed as the mean \pm SD for at least three independent experiments. Differences between two samples were assessed by a two-tailed Student's $t$ test. Differences among multiple means were assessed by one-way ANOVA followed by Bonferroni correction. $p$ values of $\leq 0.05$ were considered statistically significant.

\section{Results}

\section{Identification of the mouse Gat1 5'-flanking region}

Rapid amplification of $5^{\prime}$ cDNA ends was performed to map the transcription initiation site(s) of mouse gat1 gene. The major PCR product was cloned into pMD-18T vector and then se- 


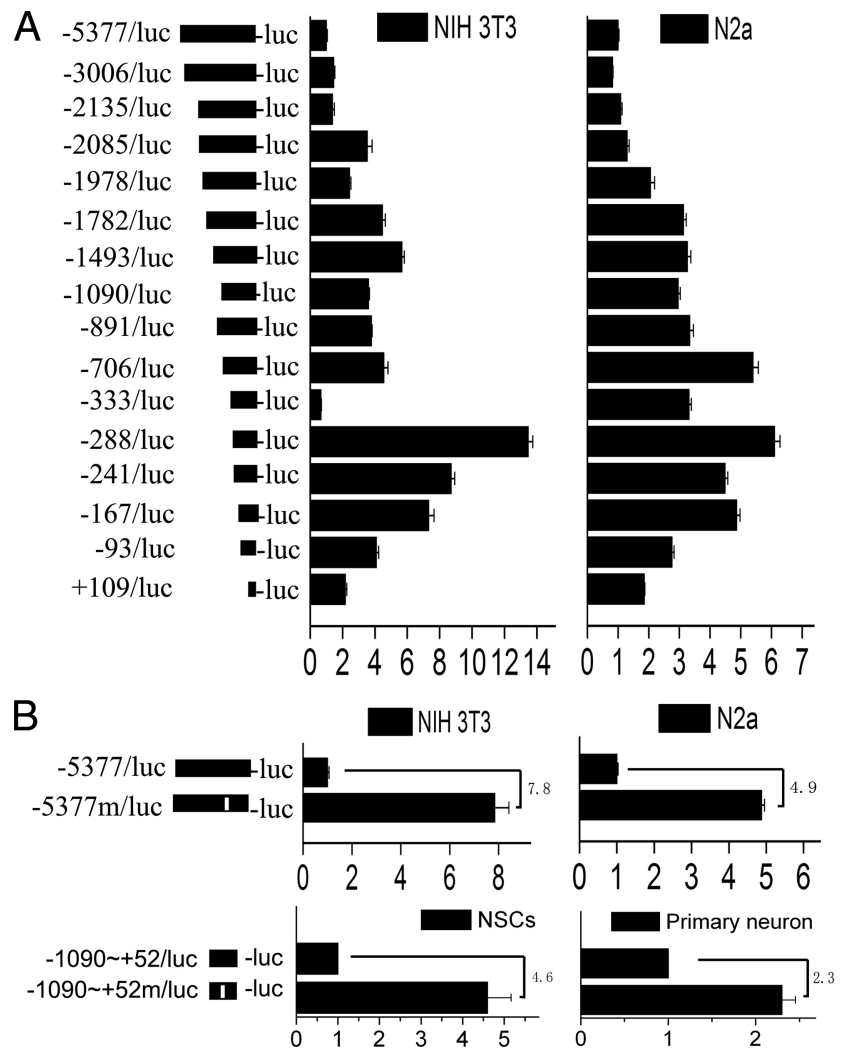

Figure 4. Transient transfection assays define a cis-regulator in mouse gat 1 gene promoter. $A$, Schematic structure of the luciferase constructs used in this study. The boundaries of the promoter constructs are defined relative to the transcription initiation site and are indicated on the left. Independent constructs were transfected into NIH 3T3 or Neuro 2a cells. Luciferase activity was normalized to Renilla luciferase activity encoded by cotransfected control plasmid pRL-SV40 and then normalized to that of $-5377 /$ luc construct. $\boldsymbol{B}$, In the $-5377 \mathrm{~m} / \mathrm{luc}$ or $-1090 \sim+52 \mathrm{~m} /$ luc construct, a 46 bp fragment, from -333 to -288 , is indicated by an open rectangle and was deleted. Independent constructs were transfected into NIH 3T3, Neuro 2a cells, primary cortical neurons, or NSCs. Luciferase activity was normalized to Renilla luciferase activity encoded by cotransfected control plasmid, pRL-SV40, or pRL-TK. The promoter activity was normalized to $-5377 /$ luc or $-1090 \sim+52 \mathrm{~m} /$ luc. Induction of promoter activity in different cell lines is indicated as fold increase. Results are shown as the mean \pm SD for three independent experiments ( $n=3$ in each independent experiment).

Table 2. Transgene expression in gat $1(5.7 \mathrm{~m})$ lacz transgenic mice

\begin{tabular}{llc}
\hline & \multicolumn{2}{l}{ gat1(5.7m)lacz transgenic founder } \\
\cline { 2 - 3 } Transgenic mice tissue & $2 \mathrm{~F}(n \geq 3)$ & $3 \mathrm{~F}(n \geq 3)$ \\
\hline Brain & 100 & 100 \\
Heart & 7.7 & 15.5 \\
Lung & 5.7 & 18.0 \\
Liver & 12.2 & 7.4 \\
Spleen & 3.8 & 2.3 \\
Kidney & 12.4 & 5.1 \\
\hline
\end{tabular}

LacZ mRNA expression in the brain of each line was artificially set at 100. Three replicates of each reaction were performed.

quenced (Fig. $1 A$ ). From the sequences of 12 independent clones, a major transcription initiation site $(+1)$ corresponding to an $\mathrm{A}$ residue was identified.

Using the sequence information for mouse gat1 gene and flanking sequence (GI:149255466) as a guide for primer design, a 5752 bp genomic fragment was cloned from mouse genomic DNA. The fragment begins inside intron 1 of mouse gat1 gene at the position $+375 \mathrm{bp}$ (using transcription initiation site as +1 ) and extends to -5377 bp upstream of the transcription initiation
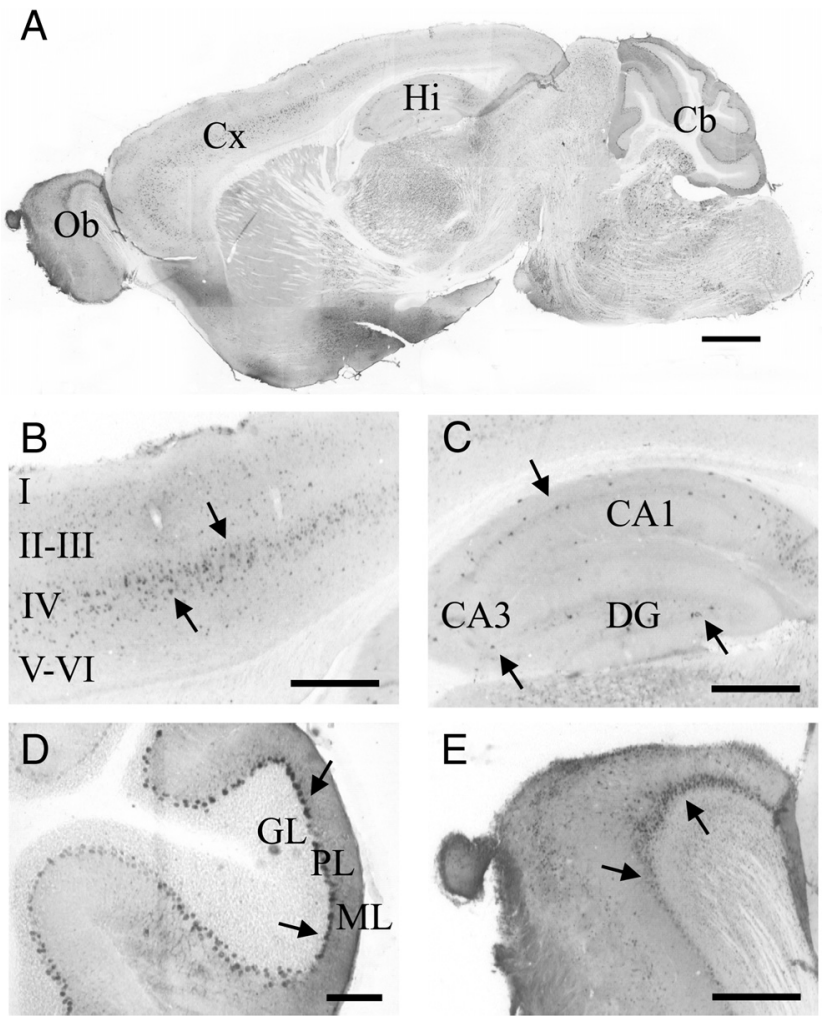

Figure 5. Histological detection of LacZ in the brain of adult gat1 $(5.7 \mathrm{~m}) /$ acz mice. $\boldsymbol{A}-\boldsymbol{E}$, Sagittal brain sections from gat $1(5.7 \mathrm{~m})$ lacz transgenic mice were stained by anti-LacZ antibodies. Shown are images of whole brain $(\boldsymbol{A})$, cerebral cortex $(\boldsymbol{C} ; \boldsymbol{B})$, hippocampus (Hi; $\boldsymbol{C}$, cerebellum $(C b ; \boldsymbol{D})$, and olfactory bulb $(0 \mathrm{~b} ; \boldsymbol{E})$. $\boldsymbol{A}-\boldsymbol{E}$, Arrows denote immunopositive cells. Scale bars: $\boldsymbol{A}$, $1 \mathrm{~mm} ; \boldsymbol{D}, 100 \mu \mathrm{m} ; \boldsymbol{B}, \boldsymbol{C}, \boldsymbol{E}, 400 \mu \mathrm{m}$.

site. Because the translation initiator ATG sequence is located inside exon 3 of mouse gat 1 gene and separated from exon 1 by two introns, the isolated 5'-flanking region of mouse gat1 gene did not contain the translation initiation site (Fig. $1 B$ ). The identity of the genomic DNA fragment was established by sequencing.

\section{Gat1 promoter activity in transgenic mice}

Transgenic mice with the gat1(5.7) lacz construct harbored a fusion gene consisting of $5.7 \mathrm{~kb}$ gat $15^{\prime}$-flanking region extending $375 \mathrm{bp}$ into the $5^{\prime}$-untranslated leader sequence, a nuclear LacZ expression cassette, and one polyadenylation site derived from the SV40 gene. Five founder lines were obtained, and all expressed the transgene as confirmed by reverse transcriptase PCR assay.

Quantitative reverse transcriptase PCR assay demonstrated almost exclusive distribution of the transgene in the brain, with minimal level of expression in peripheral tissues (Table 1). This pattern is consistent with previous results of endogenous mouse gat1 gene expression (Liu et al., 1993), indicating that the DNA fragment containing the promoter region is sufficient to confer tissue specificity of mouse gat1 gene expression.

In the two lines analyzed, GAT1 (Fig. $2 A-E$ ) and LacZ (Fig. $\left.2 A^{\prime}-E^{\prime}\right)$ immunoreactivity were detected throughout the entire cerebral cortex, hippocampus, cerebellum, and olfactory bulb. These results match the distribution of endogenous mouse GAT1 (Borden, 1996). At higher magnification, GAT1 and LacZ immunoreactivity were strong in layers II and IV and moderate in other layers of the cerebral cortex (Fig. $2 B, B^{\prime}$ ). CA1, CA3, and the dentate gyrus of hippocampus show immunoreactivity for LacZ and GAT1 (Fig. 2C, $C^{\prime}$ ). Immunoreactivity for LacZ and GAT1 

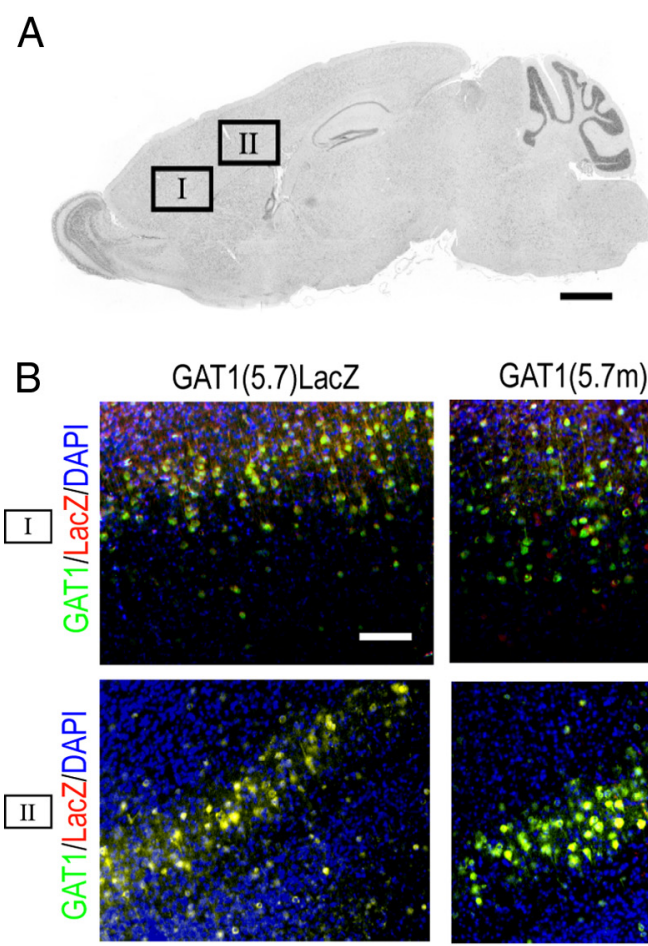

C

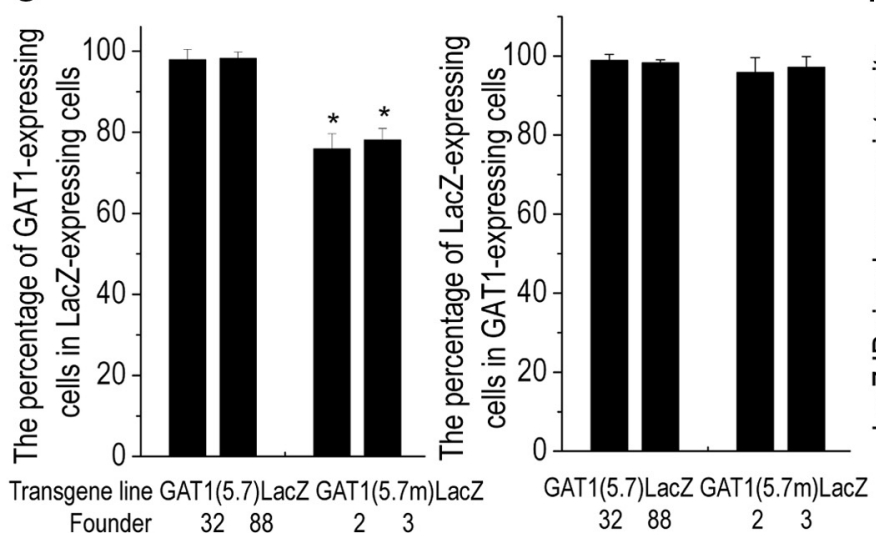

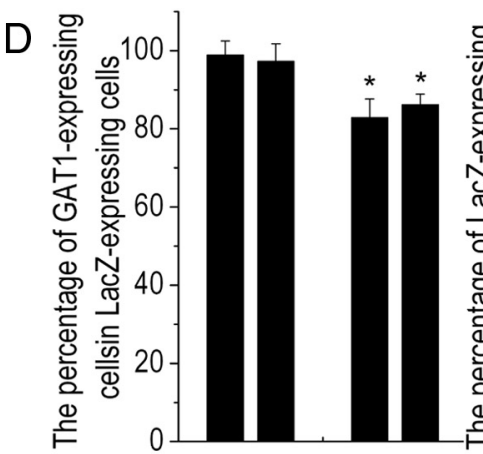
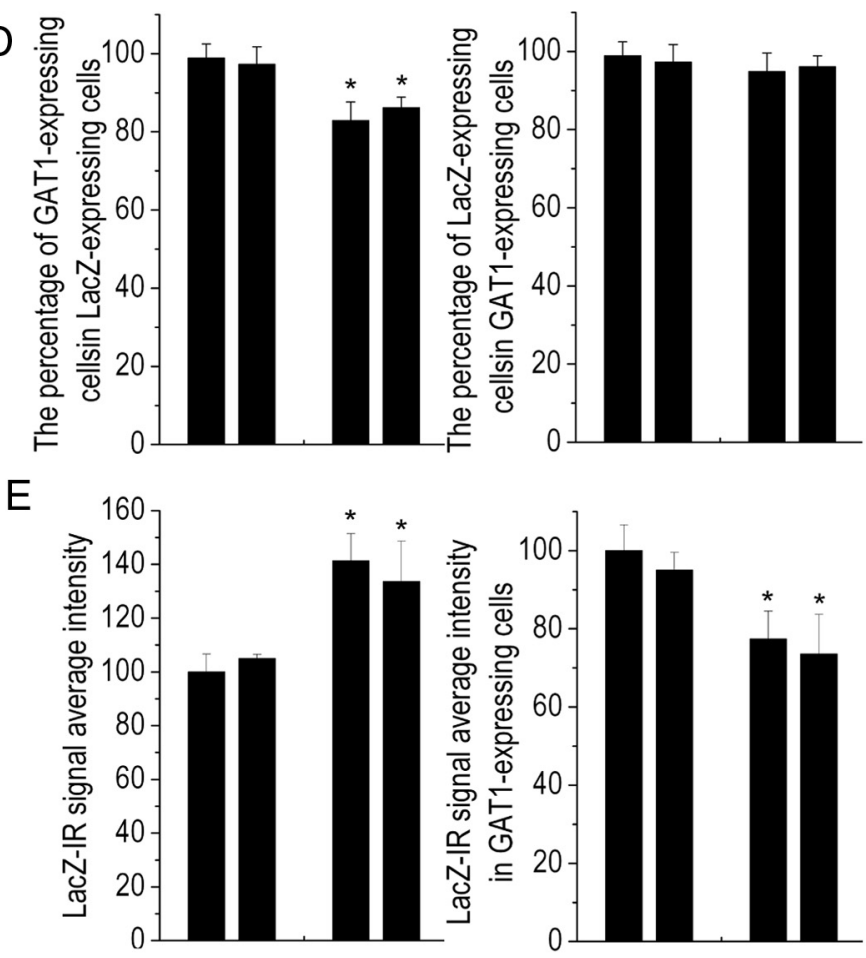

$\mathrm{F}$

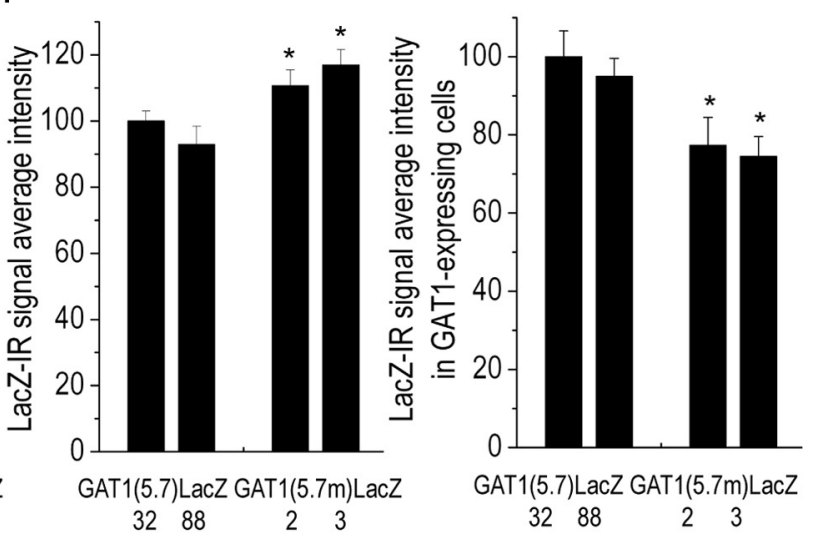

Figure 6. Quantitative analysis of LacZ or GAT1 immunopositive cells in cerebral cortex of gat1(5.7)lacz and gat1(5.7m)/acz mice. A, Schematic representation of a sagittal brain section showing image locations. $\boldsymbol{B}$, Representative images of LacZ and GAT1 immunopositive signal on sagittal brain sections from gat 1(5.7)lacz or gat 1 (5.7m) lacz mice. C, $\boldsymbol{D}$, The percentage of LacZ-expressing cells in GAT1-expressing cells or the percentage of GAT1-expressing cells in LacZ-expressing cells of region I (C) or region II (D). $\boldsymbol{E}, \boldsymbol{F}$, Intensity of LacZ-immunoreactive signal in all cells or in GAT1expressing cells of region I (E) or region II $(\boldsymbol{F})$. Scale bars: $\boldsymbol{A}, 1 \mathrm{~mm} ; \boldsymbol{B}, 100 \mu \mathrm{m}$. Data represent mean $\pm \mathrm{SE}$ ( $n \geq 5$ mice per line). ${ }^{*} p<0.05$ significantly different from gat1(5.7)lacz group (AN0VA followed by Bonferroni correction). DAPI, $4^{\prime}, 6^{\prime}$-Diamidino-2-phenylindole dihydrochloride.

was strong in the Purkinje cell layer, moderate in the molecular layer, and very faint or not detected in the granular layer (Fig. $\left.2 D, D^{\prime}\right)$. Finally, GAT1 and LacZ immunoreactivity were present in the olfactory bulb (Fig. $2 E, E^{\prime}$ ). LacZ was colocalized with GAT1 in double-staining experiments (Fig. 3). These results further indicate that the $5.7 \mathrm{~kb} 5$ '-flanking region of mouse gat 1 gene harbors most, if not all, of the cis-regulatory information required for gat1 gene expression in vivo.

\section{Definition of regulatory elements within gat1 promoter in vitro}

To localize the cis-regulatory elements that negatively regulate gat 1 gene expression, reporter gene assays were performed in two cell lines that do not have endogenous gat1 gene expression (NIH 3T3 and Neuro 2a) (Fig. 4A). In both cell lines, a strong gene expression suppression effect was observed in the constructs with $5^{\prime}$-terminal deletion up to $\mathrm{nt}-333, \sim 300$ bp upstream from the transcription initiation site. A further deletion of $46 \mathrm{bp}$ (deletion up to nt -288) abolished this effect. Moreover, an internal deletion of the $46 \mathrm{bp}$ element, from -333 to -288 , resulted in an increase of full-length promoter activity in both cell types (Fig. $4 B$ ). Similar results were achieved both in NSCs and primary cortical neurons (Fig. 4B). Notably, induction of gat 1 promoter activity observed in primary cortical neurons was significantly less than that in NSCs, NIH 3T3, and Neuro 2a. These results support the contention that the 46 bp element is an essential requirement for the negative transcriptional regulation of mouse gat1 gene.

Identification of the cis-regulatory element in gat1 promoter in vivo

Transgenic mice with the gat $1(5.7 \mathrm{~m})$ lacz construct, bearing a deletion of the 46 bp element, were established. The overall trans- 
gene expression pattern of gat $1(5.7 \mathrm{~m}) \mathrm{lacz}$ mice was not significantly different from that of gat 15.7) lacz mice (Table 2) (twotailed Student's $t$ test). These findings suggest that silencer elements other than the 46 bp element are required to prevent expression of gat1 in most non-neural tissues. Alternatively, non-neuronal tissues may lack transactivators that are critical for neuronal gene expression.

Similar to that of gat 1(5.7)lacz mice, a high level of LacZ expression was present in the cerebral cortex, hippocampus, cerebellum, and olfactory bulb in two independent lines of gat $1(5.7 \mathrm{~m})$ lacz mice (Fig. $5)$. However, the percentage of GAT1expressing cells in LacZ-expressing cells was significantly lower in brains of gat $1(5.7 \mathrm{~m}) \mathrm{lacz}$ mice than those of gat 1(5.7)lacz mice, while the percentages of LacZ-expressing cells in GAT1expressing cells were not significantly different between two transgenic mice (Fig. $6 A-D)$. These results indicate that deletion of the $46 \mathrm{bp}$ element results in an increased number of LacZ-expressing cells, part of which are GAT1 nonexpressing. It is notable that although the overall LacZ-immunoreactive signal intensity of gat $1(5.7 \mathrm{~m})$ lacz mice was higher than that of gat1(5.7)lacz mice (Fig. 6E,F), in GAT1-expressing cells the LacZ-immunoreactive signal intensity of gat $1(5.7 \mathrm{~m})$ lacz mice was lower than that of gat1(5.7) lacz mice ( $p<0.05$, ANOVA and Bonferroni correction). These results indicate that the $46 \mathrm{bp}$ element has an opposite effect on gat1 gene promoter activity depending on the cellular context.

\section{BMP2 induction of gat1 gene}

expression mediated by Smad 4 and YY1 BMP2 is reported to regulate cortical GABAergic neuron differentiation (Mabie et al., 1999; Yung et al., 2002). BMP2 increased the transcriptional activity of wild-type but not mutant gat1 gene promoter construct with the 46 bp element deleted (Fig. $7 A, B$ ). These findings indicate that the BMP2 response depends on the region in the mouse gatl gene promoter between -333 and -288 .

Sites for Smad4, the major intracellular signaling effector for BMP signals, and YY1, a reported Smad4-interacting protein (Kurisaki et al., 2003), were found in the 46 bp element (P-Match). Each two shRNA oligonucleotides for smad4 or $y y 1$ were designed and their effects were studied (Fig. 7C; supplemental Fig. S1 A, available at www. jneurosci.org as supplemental material). Inhibiting the expression of smad4 or $y y 1$ with shRNA in P19 cells or NSCs resulted in an increase of gatl gene promoter construct transcription activity, and this effect was further accentuated by a combination of
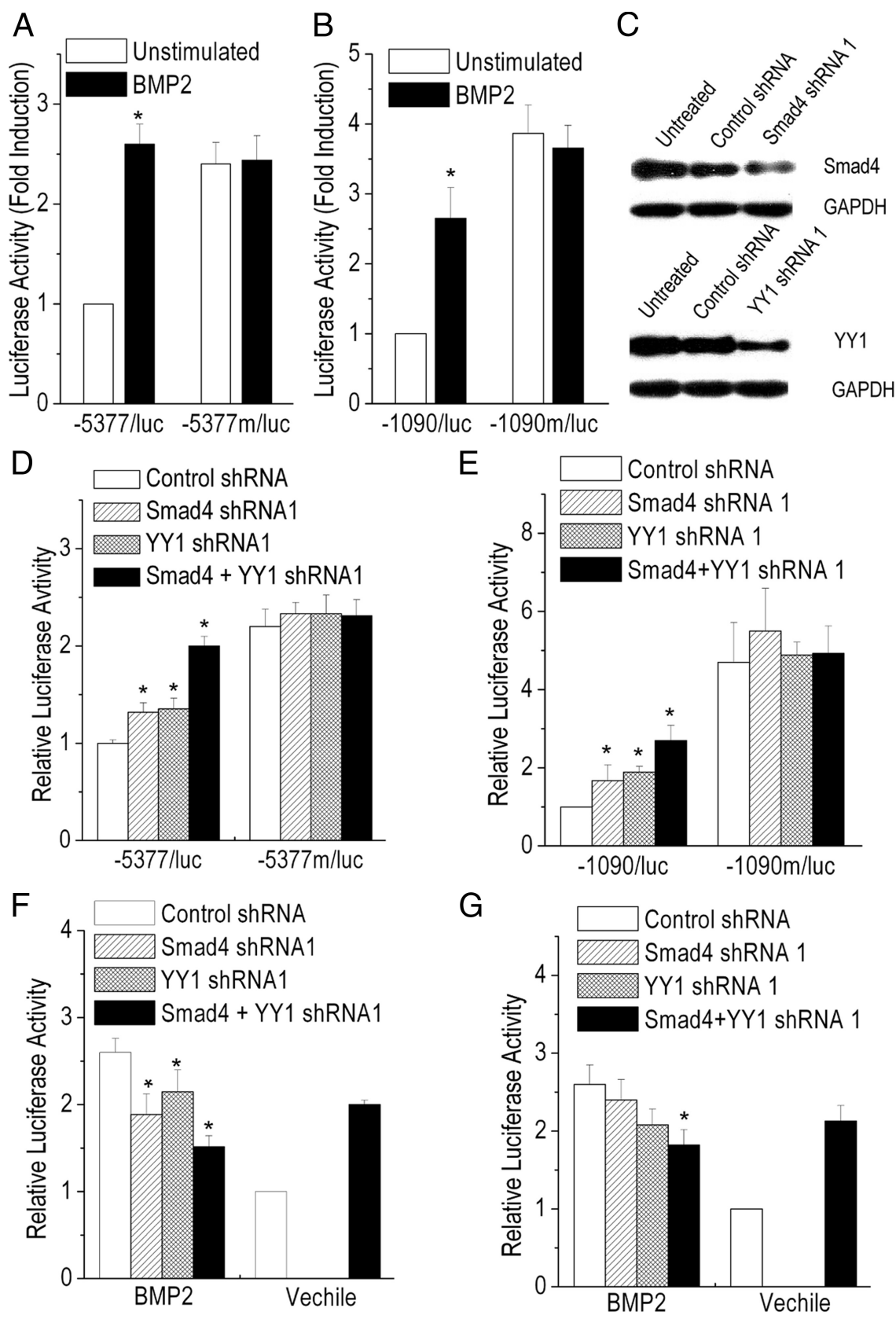

Figure 7. BMP2-induced gat1 promoter activity mediated by Smad4 and YY1. $\boldsymbol{A}, \boldsymbol{B}$, P19 cells $(\boldsymbol{A})$ or neural stem cells $(\boldsymbol{B})$ were transiently transfected with either wild-type or mutant $G$ Gat 1 gene promoter construct, grown in the presence or absence of BMP2. The activity of wild-type Gat1 promoter construct in the absence of BMP2 was set at 1. Results are expressed as the mean \pm SD for three experiments. ${ }^{*} p<0.05$, compared with the unstimulated wild-type construct control (Student's $t$ test). $\boldsymbol{C}$, The inhibitory efficiency of the shRNA directed against smad 4 or $y y 1$ evaluated by Western blot analysis. At $48 \mathrm{~h}$ after shRNA transfection, total cell lysate was prepared and normalized for protein concentration. Glyceraldehyde-3-phosphate dehydrogenase (GAPDH) was used as an internal control. Results shown are representative of three independent experiments. $\boldsymbol{D}-\mathbf{G}, \mathbf{P} 19$ cells $(\boldsymbol{D}, \boldsymbol{F})$ or neural stem cells $(\boldsymbol{E}, \boldsymbol{G})$ were transfected with either wild-type or mutant gat 1 gene promoter construct, together with the indicated shRNA expression constructs. Transfected cells were then treated with $\operatorname{BMP2}(\boldsymbol{F}, \boldsymbol{G})$ or not $(\boldsymbol{D}, \boldsymbol{E})$, as indicated. The activity of gat1 promoter construct cotransfected with control shRNA obtained in the absence of BMP2 has been set equal to 1 . Results are expressed as the mean \pm SD for three experiments. ${ }^{*} p<0.05$, compared with control shRNA (ANOVA followed by Bonferroni correction).

Smad4 shRNA and YY1 shRNA (Fig. 7D,E; supplemental Fig. S1 $B$, available at www.jneurosci.org as supplemental material). Neither Smad4 shRNA nor YY1 shRNA had an effect on the transcriptional activity of the mutant gat 1 gene promoter construct. However, in the presence of BMP2, knockdown of smad4 or yyl expression resulted in a decrease of gat1 gene promoter construct transcription activity (Fig. $7 F$, G; supple- 
A

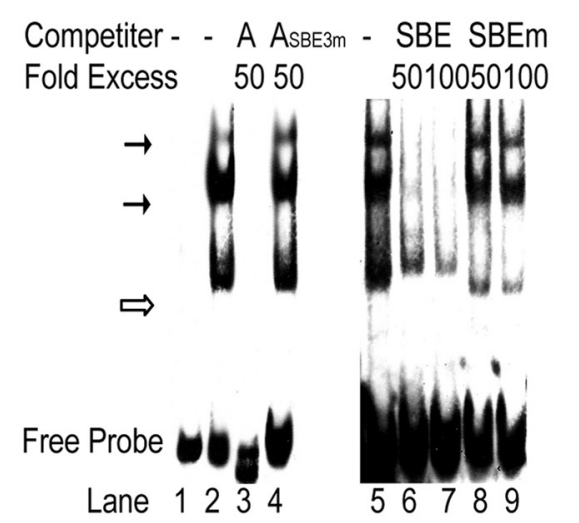

C
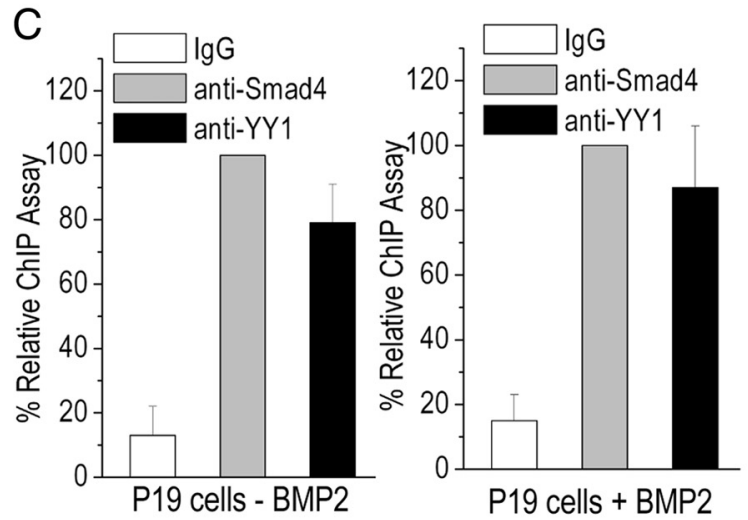

B

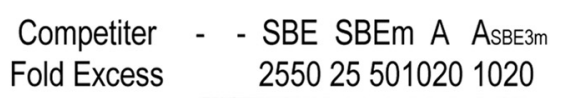

(probe A) in EMSA. Extracts from the primary cortical neurons interacted with probe $\mathrm{A}$ and revealed multiple bands on gel electrophoresis (Fig. 8A). The bands were greatly diminished by an excess of unlabeled oligonucleotide probe or unlabeled SBE oligonucleotide containing a canonical Smad4 site. In contrast, a mutant unlabeled probe $\left(\mathrm{A}_{\mathrm{SBE} 3 \mathrm{~m}}\right)$ with a mutation in functional Smad4 site (supplemental Fig. S2 A, B, available at www.jneurosci.org as supplemental material) failed to inhibit the binding activity. An unlabeled SBEm oligonucleotide containing the mutant $S \operatorname{mad} 4$ site also failed to inhibit the binding activity. Similar results also were observed in EMSA studies with extracts of NSCs (supplemental Fig. $\mathrm{S} 3 \mathrm{~A}$, available at www.jneurosci.org as supplemental material) and P19 cells (supplemental Fig. S3B, available at www.jneurosci. org as supplemental material). The binding of Smad4 to the $46 \mathrm{bp}$ element was further confirmed by EMSA experiments using a biotinylated SBE as a probe and an unlabeled wild-type or mutant probe $\mathrm{A}$ as a competitor (Fig. $8 B$ ).

Unlabeled canonical YY1-binding sites cannot inhibit the binding activity of probe A in competitive EMSAs (data not shown). It is possible that $\mathrm{YY} 1$ is tethered to DNA through interaction with another transcription factor (e.g., Smad4) in vivo, instead of binding directly to DNA. This possibility is supported by our observation that YY1 shRNA can induce the gat1 promoter construct activity, but not the mutant lacking Smad4-binding site (supplemental Fig. S2C, available at www. jneurosci.org as supplemental material).

The ChIP assay showed that Smad4 and YY1 are bound to the 46 bp element of gat1 gene promoter (Fig. 8C). Most interestingly, the Smad4-DNA and YY1-DNA interaction were detected in the chromatin from BMP2-treated P19 cells as well as in lysates derived from untreated cells. Similar results were achieved in primary cortical neurons (Fig. 8D).

\section{Discussion}

This study identified a promoter region in mouse gat1 gene with sufficient regulatory information to recapitulate endogenous gat1 expression. Deletion of the $46 \mathrm{bp}$ BMP2-responsive element resulted in

mental Fig. S1C, available at www.jneurosci.org as supplemental material). Together, these data strongly suggest that Smad4 and YY1, at least in part, mediate BMP2 regulation of gat1 gene expression.

\section{DNA-binding activity of the 46 bp element on gat 1 gene promoter}

The biotin-labeled 46 bp oligonucleotide derived from mouse gat1 gene promoter, from -333 to -288 , was used as a probe an increase in the number of LacZ-expressing cells and the overall LacZ-immunoreactive signal intensity. But, in GAT1expressing cells, deletion of the $46 \mathrm{bp}$ element resulted in a decrease in LacZ-immunoreactive signal intensity. Transcription factors Smad4 and YY1 were found to bind to the $46 \mathrm{bp}$ element and potentiate or inhibit gat1 gene transcription activity depending on the BMP2 signal in the cellular environment. 
BMPs and their receptors are abundantly expressed in the brain from early embryogenesis throughout adult life (Mehler et al., 1997; Zhang et al., 1998). Endogenous BMP signaling has been reported to influence the migration of GABAergic neurons (Li et al., 1998; Mabie et al., 1999). BMP2 has been reported to promote the terminal differentiation of striatal (Hattori et al., 1999) and cortical (Mabie et al., 1999; Yung et al., 2002) GABAergic neurons in culture. Loss of bmprla, a high-affinity receptor for $\mathrm{BMP} 2$, increases the number of calbindin-expressing GABAergic interneurons (Samanta et al., 2007). These observations collectively suggest that BMP2 plays a fundamental role in many aspects of GABAergic neurogenesis and regulation of GABAergic neuronspecific gene expression. Results from this study demonstrated that stimulation of the BMP2 signal could induce gat1 promoter constructs activity via a BMP2 response element.

Smad4 requires partners for regulating transcription of target genes (Attisano and Wrana, 2000). P-Match analysis showed that YY1-binding sites are adjacent to Smad4-binding sites in the 46 bp element of gat1 promoter. YY1 can physically interact with Smad4 both in vitro and in vivo, and functionally cooperate with Smad4 in response to BMP2 signals in epithelial and myoblastic cells (Kurisaki et al., 2003). These previous reports together with our data provide strong evidence that Smad4 and YY1 are synergistic in the regulation of gat1 promoter activity in response to BMP2 stimuli. However, more study is still needed to elucidate whether Smad4 and YY1 are required for BMP2 regulation of endogenous gat1 expression and function.

Smad4-YY1 complex binding to the cis-regulatory element had opposite effects on gat1 promoter constructs transcription activity in the absence versus presence of BMP2, suggesting the involvement of other cofactors in different cellular environment. Both Smad4 and YY1 can recruit histone acetyltransferases (e.g., $\mathrm{P} 300 / \mathrm{CBP}$ ) to form a transcriptional activation complex or histone deacetylases (HDACs) to form a transcriptional repressor complex (Austen et al., 1997; Thomas and Seto, 1999; Wotton et al., 1999; Yao et al., 2001). YY1 has been reported to repress target promoters by recruiting HDACs during oligodendrocyte differentiation (He et al., 2007). In this context, we hypothesized that the Smad4-YY1 complex recruits HDAC repressing gat1 expression in the absence of BMP2, whereas it recruits P300/CBP activating gat1 expression in the presence of BMP2 (Fig. 9). Support for this hypothesis comes from the observations that inhibition of HDACs by trichostatin A increased the Gat1 promoter constructs activity (supplemental Fig. S4, available at www.jneurosci.org as supplemental material) and that inhibition of endogenous $p 300$ or $c b p$ with shRNA abolished BMP2 induction of gat1 promoter constructs activity (supplemental Fig. S5 $A, B$, available at www. jneurosci.org as supplemental material). The response of CBPDNA interaction to BMP2 signals was confirmed by ChIP analysis on a 46 bp sequence in P19 cells (supplemental Fig. S5C, available at www.jneurosci.org as supplemental material).

Proper neuronal function requires orchestrated regulation of many genes that contribute to neurotransmitter synthesis, vesicular packaging, release, and termination. In C. elegans, the unc$25 / \mathrm{gad}$ and the unc-47/vgat were regulated by transcription factor unc-30 (Eastman et al., 1999; Westmoreland et al., 2001). So, it is reasonable to think that in mammals several common signaling molecules and transcription factors may also regulate expression of GABAergic neuron-specific genes. The promoters of gad (Makinae et al., 2000; Kobayashi et al., 2003) and vgat (Ebihara et al., 2003; Oh et al., 2005), two essential components of GABAergic neurons, have already been investigated in transgenic and transfection experiments. However, little was known about the upstream regulators, including signaling molecules and transcription factors. It is notable that adjacent Smad4 and YY1 consensus motifs were also found in the promoter regions of other GABAergic neuron-specific genes, such as gat4, gad1-2, and vgat. So, our results also provide a new idea to understand other GABAergic neuron-specific gene expression regulation.

\section{References}

Allouche A, Nolens G, Tancredi A, Delacroix L, Mardaga J, Fridman V, Winkler R, Boniver J, Delvenne P, Begon DY (2008) The combined immunodetection of AP-2alpha and YY1 transcription factors is associated with ERBB2 gene overexpression in primary breast tumors. Breast Cancer Res 10:R9.

Anderson SA, Eisenstat DD, Shi L, Rubenstein JL (1997) Interneuron migration from basal forebrain to neocortex: dependence on Dlx genes. Science 278:474-476.

Attisano L, Wrana JL (2000) Smads as transcriptional co-modulators. Curr Opin Cell Biol 12:235-243.

Austen M, Lüscher B, Lüscher-Firzlaff JM (1997) Characterization of the transcriptional regulator YY1. The bipartite transactivation domain is independent of interaction with the TATA box-binding protein, transcription factor IIB, TAFII55, or cAMP-responsive element-binding protein (CPB)-binding protein. J Biol Chem 272:1709-1717.

Bae S, Bessho Y, Hojo M, Kageyama R (2000) The bHLH gene Hes6, an inhibitor of Hes1, promotes neuronal differentiation. Development 127:2933-2943.

Baraban SC (2002) Antiepileptic actions of neuropeptide Y in the mouse hippocampus require Y5 receptors. Epilepsia 43 [Suppl] 5:9-13.

Borden LA (1996) GABA transporter heterogeneity: pharmacology and cellular localization. Neurochem Int 29:335-356.

Casarosa S, Fode C, Guillemot F (1999) Mash1 regulates neurogenesis in the ventral telencephalon. Development 126:525-534.

Chiu CS, Jensen K, Sokolova I, Wang D, Li M, Deshpande P, Davidson N, Mody I, Quick MW, Quake SR, Lester HA (2002) Number, density, and surface/cytoplasmic distribution of GABA transporters at presynaptic structures of knock-in mice carrying GABA transporter subtype 1-green fluorescent protein fusions. J Neurosci 22:10251-10266.

Chiu CS, Brickley S, Jensen K, Southwell A, Mckinney S, Cull-Candy S, Mody I, Lester HA (2005) GABA transporter deficiency causes tremor, ataxia, nervousness, and increased GABA-induced tonic conductance in cerebellum. J Neurosci 25:3234-3245.

Cossart R, Bernard C, Ben-Ari Y (2005) Multiple facets of GABAergic neurons and synapses: multiple fates of GABA signalling in epilepsies. Trends Neurosci 28:108-115.

DeFelipe J (1999) Chandelier cells and epilepsy. Brain 122:1807-1822.

de la Pompa JL, Wakeham A, Correia KM, Samper E, Brown S, Aguilera RJ, Nakano T, Honjo T, Mak TW, Rossant J, Conlon RA (1997) Conservation of the Notch signalling pathway in mammalian neurogenesis. Development 124:1139-1148.

Eastman C, Horvitz HR, Jin Y (1999) Coordinated transcriptional regulation of the unc-25 glutamic acid decarboxylase and the unc-47 GABA vesicular transporter by the Caenorhabditis elegans UNC-30 homeodomain protein. J Neurosci 19:6225-6234.

Ebihara S, Obata K, Yanagawa Y (2003) Mouse vesicular GABA transporter gene: genomic organization, transcriptional regulation and chromosomal localization. Brain Res Mol Brain Res 110:126-139.

Fode C, Ma Q, Casarosa S, Ang SL, Anderson DJ, Guillemot F (2000) A role for neural determination genes in specifying the dorsoventral identity of telencephalic neurons. Genes Dev 14:67-80.

Fueta Y, Vasilets LA, Takeda K, Kawamura M, Schwarz W (2003) Downregulation of GABA-transporter function by hippocampal translation products: its possible role in epilepsy. Neuroscience 118:371-378.

Gulacsi A, Lillien L (2003) Sonic hedgehog and bone morphogenetic protein regulate interneuron development from dorsal telencephalic progenitors in vitro. J Neurosci 23:9862-9872.

Hattori A, Katayama M, Iwasaki S, Ishii K, Tsujimoto M, Kohno M (1999) Bone morphogenetic protein-2 promotes survival and differentiation of striatal GABAergic neurons in the absence of glial cell proliferation. J Neurochem 72:2264-2271.

He Y, Dupree J, Wang J, Sandoval J, Li J, Liu H, Shi Y, Nave KA, CasacciaBonnefil P (2007) The transcription factor Yin Yang 1 is essential for oligodendrocyte progenitor differentiation. Neuron 55:217-230. 
Heilig M, Thorsell A (2002) Brain neuropeptide Y (NPY) in stress and alcohol dependence. Rev Neurosci 13:85-94.

Hirunsatit R, George ED, Lipska BK, Elwafi HM, Sander L, Yrigollen CM, Gelernter J, Grigorenko EL, Lappalainen J, Mane S, Nairn AC, Kleinman JE, Simen AA (2009) Twenty-one-base-pair insertion polymorphism creates an enhancer element and potentiates SLC6A1 GABA transporter promoter activity. Pharmacogenet Genomics 19:53-65.

Jiang KW, Gao F, Shui QX, Yu ZS, Xia ZZ (2004) Effect of diazoxide on regulation of vesicular and plasma membrane GABA transporter genes and proteins in hippocampus of rats subjected to picrotoxin-induced kindling. Neurosci Res 50:319-329.

Jiang L, Yao M, Shi J, Shen P, Niu G, Fei J (2008) Yin yang 1 directly regulates the transcription of RE-1 silencing transcription factor. J Neurosci Res 86:1209-1216.

Kabos P, Kabosova A, Neuman T (2002) Blocking HES1 expression initiates GABAergic differentiation and induces the expression of p21(CIP1/ WAF1) in human neural stem cells. J Biol Chem 277:8763-8766.

Kobayashi T, Ebihara S, Ishii K, Kobayashi T, Nishijima M, Endo S, Takaku A, Sakagami H, Kondo H, Tashiro F, Miyazaki J, Obata K, Tamura S, Yanagawa Y (2003) Structural and functional characterization of mouse glutamate decarboxylase 67 gene promoter. Biochim Biophys Acta 1628:156-168.

Kroll TT, O'Leary DD (2005) Ventralized dorsal telencephalic progenitors in Pax6 mutant mice generate GABA interneurons of a lateral ganglionic eminence fate. Proc Natl Acad Sci U S A 102:7374-7379.

Kurisaki K, Kurisaki A, Valcourt U, Terentiev AA, Pardali K, Ten Dijke P, Heldin CH, Ericsson J, Moustakas A (2003) Nuclear factor YY1 inhibits transforming growth factor beta- and bone morphogenetic proteininduced cell differentiation. Mol Cell Biol 23:4494-4510.

Lee JC, Mayer-Proschel M, Rao MS (2000) Gliogenesis in the central nervous system. Glia 30:105-121.

Lewis DA, Pierri JN, Volk DW, Melchitzky DS, Woo TU (1999) Altered GABA neurotransmission and prefrontal cortical dysfunction in schizophrenia. Biol Psychiatry 46:616-626.

Lewis DA, Hashimoto T, Volk DW (2005) Cortical inhibitory neurons and schizophrenia. Nat Rev Neurosci 6:312-324.

Liu GX, Cai GQ, Cai YQ, Sheng ZJ, Jiang J, Mei Z, Wang ZG, Guo L, Fei J (2007) Reduced anxiety and depression-like behaviors in mice lacking GABA transporter subtype 1. Neuropsychopharmacology 32:1531-1539

Liu QR, López-Corcuera B, Mandiyan S, Nelson H, Nelson N (1993) Molecular characterization of four pharmacologically distinct gammaaminobutyric acid transporters in mouse brain [corrected]. J Biol Chem 268:2106-2112.

Li W, Cogswell CA, LoTurco JJ (1998) Neuronal differentiation of precursors in the neocortical ventricular zone is triggered by BMP. J Neurosci 18:8853-8862.

Livak KJ, Schmittgen TD (2001) Analysis of relative gene expression data using real-time quantitative PCR and the 2(-Delta Delta C(T)) method. Methods 25:402-408.

Ma Y, Hu JH, Zhao WJ, Fei J, Yu Y, Zhou XG, Mei ZT, Guo LH (2001) Overexpression of gamma-aminobutyric acid transporter subtype I leads to susceptibility to kainic acid-induced seizure in transgenic mice. Cell Res 11:61-67.

Mabie PC, Mehler MF, Kessler JA (1999) Multiple roles of bone morphogenetic protein signaling in the regulation of cortical cell number and phenotype. J Neurosci 19:7077-7088.

Makinae K, Kobayashi T, Kobayashi T, Shinkawa H, Sakagami H, Kondo H, Tashiro F, Miyazaki J, Obata K, Tamura S, Yanagawa Y (2000) Structure of the mouse glutamate decarboxylase 65 gene and its promoter: preferential expression of its promoter in the GABAergic neurons of transgenic mice. J Neurochem 75:1429-1437.

Mehler MF, Mabie PC, Zhang D, Kessler JA (1997) Bone morphogenetic proteins in the nervous system. Trends Neurosci 20:309-317.

Miyoshi G, Bessho Y, Yamada S, Kageyama R (2004) Identification of a novel basic helix-loop-helix gene, Heslike, and its role in GABAergic neurogenesis. J Neurosci 24:3672-3682.

Nakatani T, Minaki Y, Kumai M, Ono Y (2007) Helt determines GABAergic over glutamatergic neuronal fate by repressing Ngn genes in the developing mesencephalon. Development 134:2783-2793.

Oh WJ, Noggle SA, Maddox DM, Condie BG (2005) The mouse vesicular inhibitory amino acid transporter gene: expression during embryogene- sis, analysis of its core promoter in neural stem cells and a reconsideration of its alternate splicing. Gene 351:39-49.

Peng W, Simantov R (2003) Altered gene expression in frontal cortex and midbrain of 3,4-methylenedioxymethamphetamine (MDMA) treated mice: differential regulation of GABA transporter subtypes. J Neurosci Res 72:250-258.

Pozas E, Ibáñez CF (2005) GDNF and GFRalphal promote differentiation and tangential migration of cortical GABAergic neurons. Neuron 45:701-713.

Rees JR, Onwuegbusi BA, Save VE, Alderson D, Fitzgerald RC (2006) In vivo and in vitro evidence for transforming growth factor-beta1mediated epithelial to mesenchymal transition in esophageal adenocarcinoma. Cancer Res 66:9583-9590.

Ruzicka WB, Zhubi A, Veldic M, Grayson DR, Costa E, Guidotti A (2007) Selective epigenetic alteration of layer I GABAergic neurons isolated from prefrontal cortex of schizophrenia patients using laser-assisted microdissection. Mol Psychiatry 12:385-397.

Samanta J, Burke GM, McGuire T, Pisarek AJ, Mukhopadhyay A, Mishina Y, Kessler JA (2007) BMPR1a signaling determines numbers of oligodendrocytes and calbindin-expressing interneurons in the cortex. J Neurosci 27:7397-7407.

Schuurmans C, Armant O, Nieto M, Stenman JM, Britz O, Klenin N, Brown C, Langevin LM, Seibt J, Tang H, Cunningham JM, Dyck R, Walsh C, Campbell K, Polleux F, Guillemot F (2004) Sequential phases of cortical specification involve Neurogenin-dependent and -independent pathways. EMBO J 23:2892-2902.

Sperk G, Schwarzer C, Heilman J, Furtinger S, Reimer RJ, Edwards RH, Nelson N (2003) Expression of plasma membrane GABA transporters but not of the vesicular GABA transporter in dentate granule cells after kainic acid seizures. Hippocampus 13:806-815.

Sussel L, Marin O, Kimura S, Rubenstein JL (1999) Loss of Nkx2.1 homeobox gene function results in a ventral to dorsal molecular respecification within the basal telencephalon: evidence for a transformation of the pallidum into the striatum. Development 126:3359-3370.

Thoeringer CK, Ripke S, Unschuld PG, Lucae S, Ising M, Bettecken T, Uhr M, Keck ME, Mueller-Myhsok B, Holsboer F, Binder EB, Erhardt A (2009) The GABA transporter 1 (SLC6A1): a novel candidate gene for anxiety disorders. J Neural Transm 116:649-657

Thomas MJ, Seto E (1999) Unlocking the mechanisms of transcription factor YY1: are chromatin modifying enzymes the key? Gene 236:197-208.

Thuault S, Valcourt U, Petersen M, Manfioletti G, Heldin CH, Moustakas A (2006) Transforming growth factor-beta employs HMGA2 to elicit epithelial-mesenchymal transition. J Cell Biol 174:175-183.

Volk D, Austin M, Pierri J, Sampson A, Lewis D (2001) GABA transporter-1 mRNA in the prefrontal cortex in schizophrenia: decreased expression in a subset of neurons. Am J Psychiatry 158:256-265.

Volk DW, Lewis DA (2002) Impaired prefrontal inhibition in schizophrenia: relevance for cognitive dysfunction. Physiol Behav 77:501-505.

Westmoreland JJ, McEwen J, Moore BA, Jin Y, Condie BG (2001) Conserved function of Caenorhabditis elegans UNC-30 and mouse Pitx2 in controlling GABAergic neuron differentiation. J Neurosci 21:6810-6819.

Woo TU, Whitehead RE, Melchitzky DS, Lewis DA (1998) A subclass of prefrontal gamma-aminobutyric acid axon terminals are selectively altered in schizophrenia. Proc Natl Acad Sci U S A 95:5341-5346.

Wotton D, Lo RS, Lee S, Massagué J (1999) A Smad transcriptional corepressor. Cell 97:29-39.

Yao YL, Yang WM, Seto E (2001) Regulation of transcription factor YY1 by acetylation and deacetylation. Mol Cell Biol 21:5979-5991.

Yung SY, Gokhan S, Jurcsak J, Molero AE, Abrajano JJ, Mehler MF (2002) Differential modulation of BMP signaling promotes the elaboration of cerebral cortical GABAergic neurons or oligodendrocytes from a common sonic hedgehog-responsive ventral forebrain progenitor species. Proc Natl Acad Sci U S A 99:16273-16278.

Zhang D, Mehler MF, Song Q, Kessler JA (1998) Development of bone morphogenetic protein receptors in the nervous system and possible roles in regulating trkC expression. J Neurosci 18:3314-3326.

Zhao WJ, Ma YH, Fei J, Mei ZT, Guo LH (2003) Increase in drug-induced seizure susceptibility of transgenic mice overexpressing GABA transporter-1. Acta Pharmacol Sin 24:991-995.

Zink M, Schmitt A, May B, Müller B, Braus DF, Henn FA (2004) Differential effects of long-term treatment with clozapine or haloperidol on GABA transporter expression. Pharmacopsychiatry 37:171-174. 